\title{
A young church in mission or maintenance mode? A case study of the Bantu Presbyterian Church of South Africa (1923-1999)
}

\section{Graham A Duncan ${ }^{1}$}

\section{Abstract}

The formation of the Bantu Presbyterian Church of South Africa in 1923 was much criticised for being the result of a racist policy; yet, had racism not been prevalent in South Africa at the time, its formation might have been unnecessary as part of the missionary outreach of the United Free Church of Scotland. For better or worse it was established and in such matters there was no going back. However, its mission was hindered by attempts to control it externally by the Scottish Church and internally by missionaries and their Mission Council. This was an unwritten maintenance approach which, in essence, militated against their missionary purpose. The first ten years of its history testify to this. Its subsequent history bears witness to the attempt to make it an authentic African missionary church open to the ecumenical scene.

Keywords: Bantu Presbyterian Church, General Assembly, missionaries, Presbyterian Church of South Africa, United Free Church of Scotland

\section{Introduction}

'The ecumenical movement does not derive simply from a passion for unity; it sprang from a passion for unity that is completely fused in the mission' [Le Guillou cited in Boegner, 1970:269]. The fact that it was largely the missionary endeavours of churches and missionary societies during the eighteenth and nineteenth centuries which gave birth to the ecumenical movement of the twentieth century, is generally accepted today (Saayman, 1984:8).

This is true of any Reformed church community, the subjects of mission and unity are integrally interrelated as can be seen from the Scottish Mission in South Africa.

The story of the first hundred years of the Scottish Mission in South Africa has been told elsewhere (Duncan, 2002; 2003; 2012; 2012a; 2013; 2013a; 2015; 2016; 2018; 2018a). This led to the formation of the Bantu Presbyterian Church of South Africa (BPCSA) in 1923 (Duncan, 2016). In her study of the history of the Scottish Mission in South Africa, Sheila Brock (1974:60) contended that, "ecclesiastical

Prof Graham Duncan is a Research Fellow in the Department of Department of Church History, Christian Spirituality and Missiology, Unisa. 
separate development in the political circumstances of South Africa since 1920 have not given much scope to the Bantu Presbyterian Church and it has not proved itself a particularly inspiring example to follow." The purpose of this article is to test the truth of Brock's assertion by examining the extent to which the BPCSA remained true to its Constitution "in the form of a self-governing Native Church" (BPCSA, 1958:113) and "an autonomous branch of the Holy, Catholic Church" (BPCSA, 1958:114) "labouring for the advancement of the Kingdom of God throughout the world" (BPCSA, 1958:115) from its formation in 1923 until union with the Presbyterian Church of Southern Africa (PCSA) in 1999. The mission of the church is summarised in section IV of the Constitution (BPCSA, 1958:117):

The vocation of the church is joyfully to bear witness to its Lord, to worship God in His Name, to build up its members in Faith and righteousness and the spirit of unity, to proclaim His Gospel to the ends of the earth, to give loving service to mankind for his sake, and to watch and pray for the coming of His Kingdom.

The ecumenical responsibility of the BPCSA was a traditional outreach component of Reformed Churches and presaged its regular involvement in church unity initiatives. It also spoke to the reconciliatory mission of the church within and beyond its borders "to the ends of the earth, to give loving service to mankind" (Duncan, 2017; 2018a, forthcoming HTS). This demonstrated its commitment to outward mission and maintenance of its historical tradition; hence, maintenance and mission were reflective of the essence of the BPCSA.

\section{The beginnings of the mission of the BPCSA}

Duncan (1997:150-151) has described the emphasis on the inclusive nature of the new denomination in the way Rev William Stuart, first Moderator of the General Assembly of the BPCSA, formally constituted the gathering and gave his Moderatorial Address in which he discussed the inaugurated approach of reconciliation. He commented that the coming together of the United Presbyterian (UP) and United Free Church of Scotland missions with the Mission Council of Natal constituted "a forward step in the line of natural development" and a result of "earnest and prayerful deliberation, full and careful consideration of the many interests involved and persons specially concerned". The highest office was open to blacks "as it ought to be," thus the new church retained the concepts of equality and parity. "The Church of Christ is for any and everyone... irrespective of nationality, colour or tongue," (BPCSA, 1923:39) though van der Spuy (1971:45) believes that this remark would have been more appropriate in the context of a united church. Nonetheless, the BPCSA "was placed in a paradoxical situation for while it claimed universality and colour blindness, its very name, composition and future relationships proclaimed something different." This was a rather negative view for it was 
open to all, as many missionaries and a few non-missionary church workers discovered. Often it was the missionaries who proved the truth of the statement for having served their working years in the BPCSA, many retired into the service of the PCSA.

However, the missionary dimension was clearly evident in Stuart's reference to the 'inaugurated approach of reconciliation.'

In loyal addresses to the King and the Prime Minister, evidence of the maintenance of traditional protocols in mainline church circles, there are references to the current situation in the country: "unrest and bitterness so widely manifest in the social and political life of the world" and to moves being made "to improve the relations between the different races in the land' that demonstrate the context in which the birth of the BPCSA has occurred and the church's social and political concern" (BPCSA, 1923:26). Fundamental to the birth of the new denomination was the ongoing role that missionaries were to play in this new context.

\section{The role of missionaries}

The role of the missionaries has to be seen in the context of the continued existence of mission councils. These had originated in 1865 and had the capacity of resilience in the face of the secessions which led to the formation of Ethiopian-type African Initiated Churches and the desire of black Christians to work out their own salvation. The mission council was:

An anachronism which served little purpose other than the care of missionaries and the control of property and finance. It was obstructive insofar as it hindered communication between the BPCSA and the Church of Scotland and did little to advance God's mission, especially through the agency of black Christians. During this period blacks were co-opted onto the Church of Scotland South African Joint Council (CoSSAJC) but they had to have proved their worth to the missionaries first by their compliance with missionary views (Duncan, 2016:1).

However, the reality was that from 1923 , there were still a number of serving missionaries who wished to continue doing so. They were granted seats in the courts of the church "with the view of giving all necessary advice and assistance, but they shall leave the conduct of business as far as practicable to the native members" (BPCSA, 1923:24). In a letter to JH Oldham, Lennox (1922) claimed that the 'full powers' accorded to missionaries would decline in the course of time until 'they will no longer be required'. This area was problematic because no checks and balances were built in to limit the missionaries' exercise of power. This was a situation which was fraught with tension which continued at varying levels of intensity in the following years (Duncan, 2016). It is interesting to note that maintenance of the missionary position was enshrined in missionary endeavours for the foreseeable future. 
Rev TB Soga expressed a desire for the blacks to have "complete control in the Native Courts" because missionaries controlled the Mission Councils. He based his case on the Plan of Union for the Scottish Churches in 1900, in which they "imposed on us [missionaries] all the duty to leave the control of the Native courts entirely to the Natives" (Lennox to Ashcroft, 1922a). Elphick (2012:2) drew out the contradictory situation the missionaries found themselves in, "The seed of South African egalitarianism was the theological proclamation of the early missionaries: that Jesus died on the cross for people of every nation and race, not for whites alone; and that, in consequence, all who accepted him were brothers and sisters." What was clear was that the missionaries had an 'ambiguous relationship' with the idea of equality with black believers and presented a 'counterideology of equality'. Contrary to white missionaries, "Black Christians... tended vigorously to assert that equality in the eyes of God should evolve into social and political equality" (Elphick, 2012:2). This was a process which had begun post 1853 and the granting of "responsible government,"” where "An emerging black leadership [educated at mission schools] was convinced that Christianity, Western education, and the colour blind franchise would open the way for blacks to attain equality with whites in common citizenship" (Elphick, 2012:3). The issue here, as expressed by Soga, relates to the autonomy of the BPCSA. The situation was encapsulated in Rousseau's (1762) comment, "Man is born free, but everywhere he is in chains."

But there was another aspect of the role of missionaries which has to be understood relating to the retention of power by mission councils:

If the Bantu Church communicate directly with the Foreign Mission Committee on any matters which relate to the council's responsibilities, the Committee will necessarily require to pass such back to the Council, who are the Committee's local Executive, for their opinion before the Foreign Mission Committee's answer to the Assembly can be given (BPCSA, 1929:49).

This is extremely significant because it strikes at the heart of the autonomy granted since a white group within the church had power to veto its decisions and wishes. At the heart of the debate was the issue of the liberation of black Christians from missionary domination exercised through mission councils, which had been a significant factor in the secessionary church movement in the late nineteenth century. Sadly, this problem was only resolved with the dissolution of the Church of Scotland South Africa Joint Council in 1981. Until this time, the mission council exercised an inordinate amount of power over an autonomous church. They were the main agents of maintenance in a missionary context as they operated, in the main, from 
mission stations while black evangelists, catechists and pastors carried out the bulk of the missionary work. This was the maintenance of a controlling approach to mission.

\section{The role of evangelists}

From the earliest days of the Scottish Mission in South Africa, indigenous Christians performed the role of 'evangelist' as catechists, teachers, pastors and ministers. In time, the specific role of evangelist emerged in areas which had not been reached by the mission and where extension work was thought to be feasible. Significant work was done by a body of unsung heroes and heroines (although women were denied recognition for their sterling contributions in this role). It was only in 1944 that the Womens' Christian Association (WCA) established a Bible Training Fund to enable women to undertake the course for the training of Bible women (BPCSA, 1944:20). This was for women "with Christian ideals and who ha[ve] shown interest in Church activities" (BPCSA, 1944:25). The General Assembly took a broad view of the participants in evangelism, "The Assembly enjoins on all ministers the remembrance that they are Evangelists and encourages them and their sessions in this the first task of the Church" (BPCSA, 1936:16). Nonetheless, it established a committee to focus on the needs and methods of evangelism that may be experimented with in congregations. It also appointed a Mission Committee to "review and help all mission work" in addition to conveying "to the members of the Church information enabling them to take a warm and practical interest in the work" and to supervise the work of evangelists (BPCSA, 1936:17). The evangelistic needs outlined above became the subject of a Missionary Night held at the 1938 General Assembly (BPCSA, 1938:31) which also received a report on a "valuable survey of evangelistic work" (BPCSA, 1938:32-34). Elders and deacons were encouraged to join in the training of evangelists at Lovedale Bible School. Significantly, the Assembly also decided "That Sessions do their utmost to encourage the Women's Christian Association and the Young Men's Christian Association to engage actively in evangelism." Conferences "for the deepening of the spiritual life" be held in congregations for office-bearers and members (BPCSA, 1938:32). The following year, the General Assembly decided:

Kirk Sessions are earnestly urged to take active steps to bring the claims of the gospel to,

(a) The mass of Heathens in our missions

(b) Our young 'school' Africans.

This would be facilitated by the presence of at least one evangelist per congregation (BPCSA, 1939:20). 


\section{Church associations}

The WCA was founded in 1893 (RPCSA, 1993:65) by Mrs. Mary Young, wife of Rev David Young, before the BPCSA was established (Nzo, 2017:77). Its original name was the Bantu Presbyterian Women's Association (BPWA). It had its roots in the 'Woman's Guild' which was founded in 1887 by the General Assembly of the Church of Scotland on the initiative of A.H. Charteris. Its aim is to "to invite and encourage both women and men to commit their lives to Jesus Christ and to enable them to express their faith in worship, prayer, and action" (Wright, 1993) (men are now permitted to join which previously wasn't the case). The BPCSA WCA regularly reported on "how the progress of the Kingdom of God could be furthered". This was clearly a missionary purpose which was consistent with the church's Constitution (§VII, BPCSA, 1924:55) and became the prime focus of the WCA. The WCA annual conference held their annual meeting during the sitting of the General Assembly and were received at one of its sessions where they always brought contributions, Isipo Somanyano, ${ }^{2}$ for specific church projects, (BPCSA, 1924:32). Although this was a distinctive African form of association, more so as it's developed, the missionaries' wives played a leading part in its witness. In time, a close and almost symbiotic link developed between the WCA and the General Assembly. The women's association took an active interest in the mission work within the Zoutpansberg area of the Transvaal (BPCSA, 1937:64). Work grew steadily and this can be seen from the formation of a branch at Gordon Memorial mission, Natal in 1924 (BPCSA, 1924:53). An interesting decision is recorded in 1927 regarding uniforms, a subject of much historical debate which has hampered the work of mission, "It was agreed that the WA brooch should be recognised as the only outward sign of the Association Membership and that uniforms be discouraged" (BPCSA, 1927:38). The WCA was particularly committed to the support of the leper colony at Emjanyana (BPCSA, 1930:56), as was the General Assembly, as part of their missionary outreach. It further developed this work among young women in the church by establishing a Girl's Association (BPCSA, 1937:65). The 1971 report (BPCSA, 1971:54-70), Bantu Presbyterian Church of South Africa: Origin and progress. In a section headed 'Workers and their achievements: Minister and Elders' paid tribute to the sterling work of mission pursued by the WCA and the Girls' Association (GA) (1923-1970).

The idea of establishing a Young Men's Christian Association (YMCA) was first mooted in 1935 "to cooperate the evangelical word under the Church." Draft proposals were requested at the 1936 Assembly (BPCSA, 1935:35). In 1947 (BPCSA 1948:9), the name of the men's association was changed to the Young Men's Christian Guild. Its constitution was ratified by the 1958 General Assembly with aims similar to those of the WCA:

2 Women's Guild gifts. 
a) To advance the Kingdom of God in our church, in other sister Churches and throughout the world.

b) To deepen the spiritual lives of our young men and to promote the study of the Scriptures among them and the intellectual, social and physical well-being of our youth.

c) To foster loyalty to our Church and to the church of Christ as a whole (BPCSA, 1958:39).

This expresses a universal obligation to promote God's mission within an ecumenical perspective as it follows the pattern of Jesus' holistic development, spiritually, physically, intellectually and socially (Luke 2:52).

\section{Theological education}

Since the opening of the South African Native College at Fort Hare in 1916, it was anticipated that the new denomination would have some kind of formal relationship with the college in addition to its training centre at Lovedale. It was decided to enter discussions with the Presbyterian Church of South Africa regarding cooperation in theological education (BPCSA, 1924:20-21). A new syllabus was also to be considered (BPCSA, 1924:22) in a context where the European model of theological education had been adopted and implemented. This became particularly problematic with regard to entrance qualifications which were retained at a high level (BPCSA, 1930:34). This indicated a commitment to maintenance of the European model which would endure even into and beyond the union which brought the Uniting Presbyterian Church in Southern Africa into being in 1999.

One of the first practical tasks in theological education was to determine the best manner in which probationer ministers could be incorporated into the life and work of the BPCSA (BPCSA, 1924:19). A committee was established to work on this. The nature of the high calling was expressed by the General Assembly in 1935 (BPCSA, 1935:20) as a matter for serious prayer and consideration as it commended:

The vocation of the ministry, with its opportunity for heroic and sacrificial service. The Assembly affirms its conviction that such service of Christ demands the highest possible training together with special qualities of consecration and spiritual experience, and therefore appeals to young men aflame with love for Christ for the dedication of their lives to His Ministry.

This indicates a strong awareness of the necessity of spiritual maturity in addition to educational ability for the demanding work of God's mission which it describes as "heroic and sacrificial service" in a missionary context, but also to maintain the life 
and work of the denomination through its ministry. Apart from the BA (Theology) course, students were also able to enroll for a Diploma in Theology at the University of Fort Hare by 1940 (BPCSA, 1940:5, 8). However, there was no indication of a theological education in and for the African context and hence no understanding of the missionary needs of outreach to African peoples.

Substantial progress was made on the furtherance of mission and unity when the establishment of the Federal Theological Seminary was proposed (BPCSA, 1960:270; Denis \& Duncan, 2011:41-47). This was to become an experiment in mission and ecumenism which provided a serious challenge to the apartheid government. The proposed site was at Lovedale on land held in trust by the Church of Scotland for the BPCSA.

A 'Special Commission on the Church Ministry' reported to the General Assembly in 1971 (BPCSA, 1971:48-49) arising out of a concern for the lack of candidates offering for the ordained ministry. This problem posed a threat to the maintenance of the church, let alone its missionary outreach. A number of relevant issues were raised but the matter of the lack of lay education, "a priceless contribution to God's work" (BPCSA, 1971:48) was highlighted as a vital component of mission work. This was clearly a hindrance to mission in addition to the discerned problems of lack of contact and poor impact of ministers due to having to minister to large extensive congregations.

In 1976, a further ecumenical and missionary advance was made when it was agreed to merge the Congregational Adams United College with the Presbyterian St Columba's College to form Albert Luthuli College at the Federal Theological Seminary (BPCSA, 1976:180). The seminary closed in 1993 (RPCSA, 1993:75) and the training for ministry of the RPCSA, EPCSA and UCCSA programme transferred back to the University of Fort Hare (RPCSA, 1994:30). There were a number of reasons for the closure and the ending of apartheid was certainly one of them (Duncan, 2004:1-31).

\section{Life and work}

The supply of ministers in large and widely scattered parishes was met by a decision to allow licenced probationers to celebrate the sacraments in such places (BPCSA, 1924:19). Mission was at the heart of the Committee on Life and Work interests as can be seen from a deliverance of the 1938 General Assembly (BPCSA, 1938:13), "Office-bearers and ministers should use their best mental faculties in discovering special methods of wooing young men and women for Christ. The Church needs live young folk to step in and take the vows for the furtherment of our Church." It was at this time that the Assembly replaced the word "Native" with "African" in its usage (BPCSA, 1938:16). 
The 1971 General Assembly received a significant historical report (BPCSA, 1971:54-70), 'Bantu Presbyterian Church of South Africa: Origin and progress.' In the section "Workers and their achievements: Minister and Elders," the important work of Church extension (mission) was attributed to a series of ministers (missionaries and black) who had taken an active and enthusiastic role in missionary work. In addition, many elders were also praised for their contributions in this regard. The report concluded:

When we remember those gone before us, and the splendid work done to the glory of God and the spiritual benefit of our people, we should double our efforts and in our time pray for the Spirit to lead us to greater achievements (BPCSA, 1971:70).

Mission was integral to the work of the Church in the past and would remain so for the future.

This view was consolidated in 1974 (BPCSA, 1974:56-57) as the result of the report of an ad hoc committee which led to the affirmation of a number of functions of the denomination:

a) To convert people to Christ ...

b) To encourage and strengthen those who are already members of the Church ...

c) To serve the community in all its aspects - spiritual, social, physical and mental ...

d) To be a conscience to those in authority ...

e) To promote and have fellowship with other church bodies in South Africa and throughout the world ...

This was a comprehensive missionary mandate for the BPCSA to embark upon as it entered its second half century since its foundation.

A significant change occurred in 1978 with a decision to change the name of the BPCSA to the 'Reformed Presbyterian Church in Southern Africa' with effect from 1 January 1979 (BPCSA, 1978:22). This was to account for the negative connotations of the term 'Bantu' in addition to the desire of some who were prepared to accept the homeland system making the inhabitants of so-called Bantustan citizens of southern Africa rather than South Africa. An example of this was Rev Gladwin T Vika, General Secretary of the BPCSA, who resigned his position (BPCSA, 1977:18) to become Minister of Health and, subsequently, Minister of Foreign Affairs in the Transkei government.

The following years' plans to open the Lovedale Lay Education Centre were approved (RPCSA, 1979:26). This was to replace the Lovedale Bible School which had been expropriated by the government to facilitate development at Fort Hare University in 1974 (BPCSA, 1974:46). After a promising start in planning, the project was 
abandoned in 1982 due to "the unsettled political situation surrounding [the sale of] Lovedale" (RPCSA, 1982:19).

\section{Socio-political issues}

These issues all focused in one way or another on the matter of racial segregation both unofficial, prior to 1948, and official, afterwards. This impacted on the Church at large in a number of ways. Addressing the General Assembly in 1974, the Moderator, Rt Rev Gladwin Vika declared:

... Government continues, through legislation, to create more problems for us as the process of visas and permits through which workers from abroad have to pass is becoming more stringent by the day (BPCSA, 1974:50).

He noted how much division this had caused both within the Church and beyond (BPCSA, 1974:50-54) and how it had "been the tendency of the Church for too long in our country to soft pedal any areas which are likely to irritate the government of State". Referring to the detrimental influence of a strong pietism and individualism, he accused the BPCSA, "The problem is that the Church is too Christian to be involved in matters, yet the Galilean Boy became a controversial figure from the age of twelve" (BPCSA, 1974:51). His address was a clarion call to the BPCSA to reorient itself for mission in areas hitherto considered to be secular, in spite of the potential threat of reprisals from the government.

Temperance arose out of a serious social and economic issue which was part of an attempt to control and dominate black people, as well as destroy them morally and physically (Beinart, 1994:38, 104, 143). In 1926, the General Assembly of 1926 called for total abstinence and for the introduction of fermented wine at Holy Communion (BPCSA, 1926:32-33). This remained the policy of the BPCSA even when it was obeyed more in the breach than in conformity, ably supported by the WCA. In 1927, the General Assembly reminded, "Congregations, kirk sessions, deacons' courts and ministers that it has been the inherited and established custom of the Bantu Presbyterian Church to insist on total abstinence from intoxicating liquors..." (BPCSA, 1928:16). This decision was strongly supported by the WCA (BPCSA, 1928:50) who related this to personal purity (BPCSA, 1931:61) which became a regular theme in their annual meetings. At this time temperance meant 'total abstinence.' This was a missionary activity because alcohol was the cause of many other related social issues including marriage problems, poverty and unemployment. The Assembly was concerned for the welfare of its members as can be seen from the decision to petition the Prime Minister regarding the extension of the tot system, "The Assembly views with amazement and sorrow the proposal to extend 
the tot system to the Transvaal and to give facilities for the spread of the drinking of European liquors amongst the Natives" (BPCSA, 1930:16). But this was extended in 1930 to include "the practice of grinding beer, drinking and hiring people to work for Utywala ${ }^{3}$ within mission boundaries" (BPCSA, 1931:20). This had a particularly deleterious effect on migrant workers and, consequently, their families. It also had serious implications for the status of the Christian family as one agent in promoting the mission of the Church. The General Assembly decision was regularly reaffirmed (BPCSA, 1959:15) throughout its existence.

Another contentious issue related to the pass laws. The 1927 General Assembly passed a resolution protested through, "That Mr. Soga's protest be sent to the press and that a protest against members of the Assembly requiring to carry passes be sent to the Assembly to the authorities responsible for the regulations" (BPCSA, 1927:12), This was a deviation from the principle of freedom of movement which would seriously hamper the missionary work of the BPCSA. Related to this, the General Assembly deplored the passing of the Group Areas Act again as it would interfere with the missionary outreach of the Church:

1. Contrary to the righteous will of God which calls his children to act with equal justice towards their brothers, in those proclamations so far made under the Act certain sections of the community are being unjustly penalised.

2. The work of several of our congregations existing for many years is to be disrupted by the removal of the members, the cancellation of long established business interests and the expropriation of extensive church buildings without adequate compensation (BPCSA, 1958:24).

The relationship of justice to the mission of the Church is emphasised as the historical work was undermined and restricted. The land issue demonstrated the government's lack of understanding and sensitivity in a matter which was not only social and economic, but also deeply religious.

A further matter arose in response to a national movement against the restrictive apartheid legislation, the General Assembly took a strong stand in favour of passive resistance on the grounds that it was sanctioned by scripture as a response to gross injustice, not sourced "in the lower nature of men, but in their partial grasp of the transforming truth that they too, are people of God and sons of the highest" (BPCSA, 1952:36). The Assembly noted the gravity of the situation:

As the campaign intensifies the difficulties and incitements will increase, and only as our people can continue to behave non-violently and without bitterness to any

3 An alcoholic beverage. 
man, will their endeavours be found worthy of the blessing of God the Father, Who in the person of His Son, Jesus Christ, died upon the cross that we might be reconciled to Him and to each other (BPCSA, 1952:36).

Here we have the essence of God's mission in which the Church is the main agent. The ultimate aim of God's mission is reconciliation. This offers a rationale for socio-political engagement based on the BPCSA's adherence to the supreme authority of the scriptures.

The passing of the Bantu Education Act in 1953 was a blight on the distinguished mission work in education by a number of churches, not least the Bantu Presbyterian Church. It evoked an immediate response from the General Assembly in 1954 :

The General Assembly place on record its regret that the government has embarked on a scheme of education which seems to place emphasis on preparing pupils for a subordinate role in the country's life rather than giving them the common culture of the Christian West.

This could have been accomplished without displacing missionary management of existing schools, particularly as only one third of Bantu children are in school (BPCSA, 1954:22).

A decision was made not to sell church properties which housed schools, but rather to lease them to the government. This undermined one of the most significant and successful means of promoting ecumenism and mission within the total community. Concerns in this regard were expressed regularly at General Assembly (BPCSA, 1976:290). Schools and colleges directly affected were Emgwali School for girls, Pholela institution, Blythswood Institution and the renowned Lovedale Missionary Institution. In 1976 when students protested against the enforcement of Afrikaans as the medium of instruction in schools the General Assembly issued a statement:

... after several years of Bantu Education we find it unacceptable, and request the government to give our children the same education as is given to other races in South Africa (BPCSA, 1976:32, 36).

This was a rather mild rebuke for a situation in which children's life prospects were being severely diminished.

This situation was further exacerbated by unrest in universities and the matter provoked a sharp response from the General Assembly in 1972 (BPCSA, 1972:33). This was provoked by the students at the Federal Theological Seminary (BPCSA, 1974:53). The Assembly urged the opening of South African universities to all on 
the basis of meeting entrance requirements and the avoidance of measures which would provoke the students.

In the prelude to 'States of Emergency: 1985 - 1987,' as the situation in the country deteriorated under the increasing encroachment of apartheid policies on the life of South African citizens, The General Assembly of the RPCSA sent an appeal to the State President. In 1984. It challenged the government regarding its legislated separatist policies as a threat to the mission of the church:

The mission of the church is severely restricted by apartheid laws which affect the movement and deployment of ministers... In order to satisfy the demands of apartheid; people are divided into white, coloured, indian and black, and the blacks are further divided into ethnic groups and communities. Black communities are forced to move from their land to areas earmarked for them. Such forced removals destroy the communities affected, reduce them to poverty by imposing building programmes they can ill afford, deny them the basic right to settle where they choose to settle; generate bitterness, hatred and insecurity; impose untold suffering and disrupt the work of the church (RPCSA, 1984:45-46).

It is interesting to note that the Dutch Reformed Church, a church historically renowned for its commitment to mission beyond the borders of South Africa (Saayman, 2007:45-68) should place such restrictions on mission within its borders. The missionary intent of the appeal was clear:

The Church in terms of the great commission (Matthew 28:16) is commissioned to preach the gospel to all nations; therefore, the apartheid prescription that you preach to your own people is a violation of Christ's commission.

The Church is called upon to proclaim and practice reconciliation. The God who was in Christ reconciling the world to Himself has entrusted unto the Church the same ministry of reconciliation. Apartheid forces Christians to believe its heretical pronouncements that people are irreconcilable (RPCSA, 1984:45).

Here was the heart of the missionary enterprise, the ministry of reconciliation. The missionary commitment of the RPCSA was to a reconciled community rather than a separated community. In this way, it was to remain committed to one South African society and opposed to the homelands policy. It refused to draw distinctions between people, even black people. This was a dynamic process which would not permit the RPCSA General Assembly to with meaningless platitudes about all being "one in Christ" (Galatians 3:28). The government proceeded in a dynamic manner by instituting states of emergency when and where threats to its authority were discerned. 
When states of emergency were instituted, the General Assembly noted "with regret that since the introduction of the state of emergency regulations a great number of blacks have been victims of the so-called state of emergency" (RPCSA, 1987:33). Such wording indicated that the General Assembly did not trust the authenticity and integrity of the state of emergency or the government's use of such a mechanism to control the population.

\section{Gender issues}

Despite earlier moves to include women in the eldership and ministry on the church (Duncan, 2019:4-6), it was decided that they were to be included in the representatives at presbytery, General Assembly and assembly committee levels (RPCSA, 1997:63). Awareness workshops were held to facilitate this process. The first woman to be ordained was Rev Charity Majiza in 1978 (Duncan, 2019:4). A number of others followed.

\section{Ecumenical thrust and progress towards union}

Following many false starts and abortive attempts throughout the twentieth century (Duncan, 2018a; 2018b; 2019), the General Assembly accepted the principle of union with the PCSA (RPCSA, 1996:59) in 1996 and from this time much missional energy was devoted to securing the union which was consummated on 26 September 1999 in Port Elizabeth.

In addition, the BPCSA/RPCSA has always had a strong ecumenical thrust which was integral to its mission. It engaged with the South African Council of Churches and its regional agencies were active in the All Africa Council of Churches, The World Alliance of Reformed Churches and the World Council of Churches, as well as a number of overseas churches (Duncan, 2002:194).

\section{Conclusion}

It is clear from the above that the Bantu (Reformed) Presbyterian Church of South Africa was engaged in mission throughout her lifespan. There was tension and a striving after a balance between the maintenance and missionary models of the church. Both were necessary - maintenance of the institution to prepare its members for mission; and mission to advance the causes which the BPCSA embraced to further the coming kingdom of God. While foreign missionaries continued to decline in numbers, the black membership took an increasingly responsible role on the governance and witness of the denomination as an agent of mission in South Africa. However, it was often these missionaries who acted as a restraining force in the development of an African indigenous church and were representative of the maintenance mode of mission. In this regard, they acted against the principles of 
mission and of the United Free Church of Scotland which sent them as it sought to encourage the growth of an autonomous church. This mission was not restricted to the realm of evangelism but saw an outlet in engagement in social and political issues too. Despite limited resources and in the face of oppression the BPCSA/ RPCSA managed to fulfil her God ordained mission of promoting and extending the kingdom of God within her capabilities.

\section{Works consulted}

Bantu Presbyterian Church of South Africa. 1923, 1924,1926, 1927, 1928, 1930, 1931, 1935, 1936, 1937, 1938, 1939, 1940, 1944, 1948, 1952, 1954, 1958, 1959, 1960, 1971, 1972, 1974, 1976, 1978. Proceedings of the General Assembly of the Bantu Presbyterian Church of South Africa. Lovedale: Lovedale Press.

Bantu Presbyterian Church of South Africa. 1958. Manual of law, practice and procedure in the Bantu Presbyterian Church of South Africa (renamed) Reformed Presbyterian Church of South Africa. Lovedale: Lovedale Press.

Beinart, W. 1994. Twentieth century South Africa. Cape Town: OUP.

Boegner, M. 1970. The long road to unity: Memories and anticipations. London: Collins.

Brock, S.M. 1974. James Stewart and Lovedale: A reappraisal of missionary attitudes and African response in the Eastern Cape, South Africa, 1870-1905. PhD thesis, Edinburgh: University of Edinburgh.

Denis, P. \& Duncan, G.A. 2011. The native school that caused all the trouble: A history of the Federal Theological Seminary of Southern Africa. Pietermaritzburg: Cluster.

Duncan, G.A. 1997. Scottish Presbyterian Church Mission Policy in South Africa, 18981923. MTh dissertation. Pretoria: University of South Africa.

Duncan, G.A. 2002. The Reformed Presbyterian Church in Southern Africa - heritage and legacy. In P. Coertzen (ed). 350 years Reformed. Stellenbosch: CLF.

Duncan, G.A. 2003. 350 years Reformed in South Africa: The contribution of the Reformed Presbyterian Church in Southern Africa. HTS/Theological Studies 59(1), 47-64.

Duncan, G.A. 2004. Its end foreshadowed in its beginning: The closure of the Federal Theological Seminary. Studiae Historiae Ecclesiasticae XXX(1), 1-31.

Duncan, G.A. 2012a. 'Pull up a good tree and push it outside'? The Rev Edward Tsewu's dispute with the Free Church of Scotland Mission. NGTT 53(1/2), 50-61.

Duncan, G.A 2012. The role of Mission Councils in the Scottish Mission in South Africa: 1864-1923. Studia Historiae Ecclesiasticae XXXVIII(1), 217-234.

Duncan, G.A. 2013a. 'African churches willing to pay their own bills': The role of money in the formation of Ethiopian type churches with particular reference to the Mzimba Secession. African Historical Review 45(2), 52-79.

Duncan, G.A, 2013. The origins and early development of Scottish Presbyterian mission in South Africa (1824-1865). Studia Historiae Ecclesiasticae XXXIX(1), 205-220.

Duncan, G.A. 2015. The migratory dimension of Scottish Presbyterianism in Southern Africa. African Historical Review 47(2), 89-118. 
Duncan, G.A. 2016. The formation of the Bantu Presbyterian Church of South Africa. International Journal of African Historical Studies 49(3), 329-360.

Duncan, G.A. 2016. Mission Councils: A self-perpetuating anachronism (1923-1971): A South African case study. SHE, 11.

Duncan, G.A. 2018. 'Tiyo Soga (1829-1871) at the intersection of "universes in collision"”. HTS Teologiese Studies/Theological Studies 74(1), 4862.

Duncan, G.A 2018a. To unite or not to unite? That is the question: A case study of Presbyterianism in South Africa, 1897-1923. Acta Theologica 38(1), 37-60.

Duncan, G.A. 2018b. Mission to Church - Church to mission?: The Bantu Presbyterian Church of South Africa: The first ten years, 1923-1933. Missionalia 46(3).

Duncan, G.A., 2019. South African Presbyterian women in leadership in ministry (19732018). HTS Teologiese Studies/Theological Studies 75(1).

Duncan, G.A. 2019. The Bantu Presbyterian Church in South Africa and Ecumenism, 19401999. HTS (forthcoming).

Elphick, R. 2012. The equality of Believers: Protestant Missionaries and the racial politics of South Africa. Charlottesville \& London: University of Virginia Press.

Lennox, J. 1922a. Lennox to Ashcroft, 30 August 1922, Letterbook, Mission Council, Howard Pym African Library (HPAL), University of Fort Hare.

Lennox, J. 1922. Lennox to JH Oldham, 11 December 1922, Lennox papers Box 25, F91100, F218-224, NAHECS, UFH.

Mission Council of South Africa, Relation of Mission Councils to Bantu Presbyterian Church, FMC note 2154, 1923, Lennox papers, Box 12, F91-100, NAHECS, UFH.

Nzo, M. 2017. The Bantu Presbyterian Church in South[ern] Africa: Its origins and history. Unpublished manuscript.

Reformed Presbyterian Church in Southern Africa. 1979, 1982, 1984, 1989, 1993, 1996, 1997. Proceedings of the General Assembly of the Reformed Presbyterian Church in Southern Africa. Lovedale: Lovedale Press.

Roussouw, J.J. 1762. The social contract. Available from: https://www.sparknotes.com/philosophy/socialcontract/summary/ (Accessed 7 February 2010).

Saayman, W.A. 1984. Unity and mission: A study of the concept of unity in ecumenical discussions since 1961 and its influence on the world mission of the church. Pretoria: UNISA Press.

Saayman, W.A. 2007. Being missionary being human: An overview of Dutch Reformed mission. Pietermaritzburg: Cluster.

South African history Online. 2012. States of Emergency in South Africa: The 1960s and 1980s. Available from: https://www.sahistory.org.za/topic/state-emergency-south-africa-1960-and-1980s (Accessed 25 February 2019).

Wright, D.F. 1993. Woman's guild. In D.F. Wright (ed). Dictionary of Scottish Church History and Theology. Edinburgh 1993. 